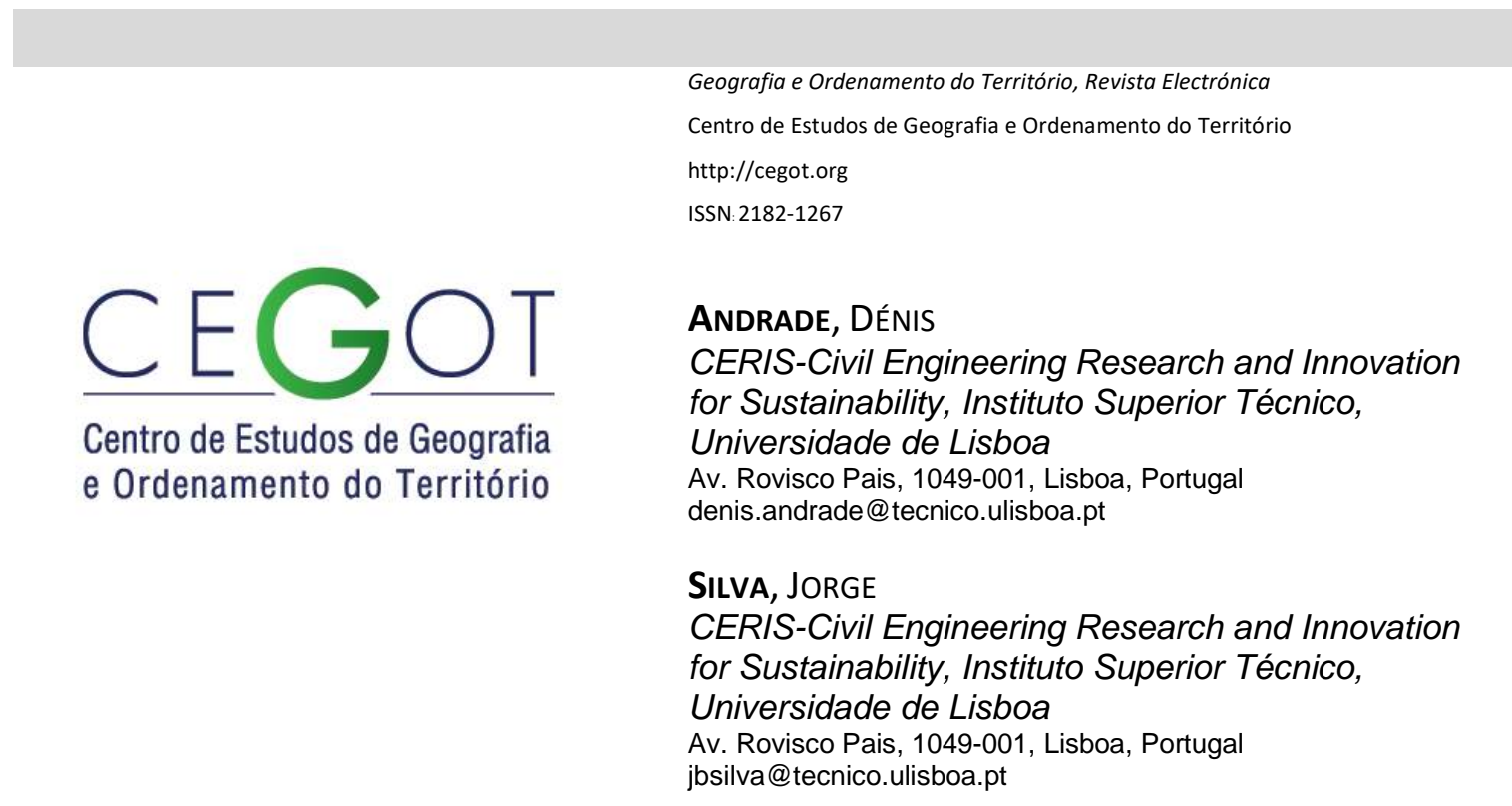

\title{
Contributos para uma estrutura de ordenamento da cidade-ilha de Mindelo-S. Vicente
}

Contributions to a spatial planning structure of the city-island of Mindelo-S. Vicente

Referência: Andrade, Dénis; Silva, Jorge (2017). Contributos para uma estrutura de ordenamento da cidadeilha de Mindelo-S. Vicente. Revista de Geografia e Ordenamento do Território (GOT), n.o 11 (junho). Centro de Estudos de Geografia e Ordenamento do Território, p. 7-31, dx.doi.org/10.17127/got/2017.11.001

\section{RESUMO}

Este artigo pretende analisar a estrutura urbana da cidade do Mindelo e contribuir para uma proposta de estrutura de ordenamento para a ilha de S. Vicente. Procede-se à caracterização base da ilha de S. Vicente, dando ênfase aos fatores de localização do Mindelo, a principal aglomeração. A estrutura urbana do Mindelo é, em grande medida, o resultado dos sucessivos planos urbanísticos que condicionaram a sua evolução. Das cartas de ocupação do solo dos últimos 45 anos foi possível mapear a evolução da mancha urbana e a identificação dos seus elementos estruturantes. Da conjugação das três linhas estratégicas do diagnóstico, foram estabelecidos contributos para a elaboração de um plano de estrutura para a cidade-ilha de Mindelo-S. Vicente, destacando-se a coesão urbana, a sustentabilidade ambiental e o desenvolvimento económico.

Palavras-chave: cidade do Mindelo, coesão urbana, ambiente sustentável, planos urbanísticos, estrutura de ordenamento, Cabo Verde

\section{ABSTRACT}

This article intends to analyze the urban structure of the Mindelo city and make a contribution to a spatial structure for the island of S. Vicente. For this purpose, the basic 
characterization of the island of S. Vicente was carried out, emphasizing the factors that contributed to the location of Mindelo, as its main urban agglomeration. The urban structure of Mindelo, to a large extent, is the result of the urban plans that conditioned its evolution. Based on available planned land use maps (last 45 years) it was possible to map the evolution of the urban area and the identification of its most relevant structuring elements. Finally, from the combination of the three strategic lines of diagnosis, contributions were established for the elaboration of a structural plan for the city-island of Mindelo-S. Vicente, that ensures the urban cohesion, environmental sustainability and economic development.

Keywords: Mindelo city, urban cohesion, sustainable environment, urban development plans, urban structure, Cape Vert

\section{Introdução}

O presente trabalho visa analisar a evolução da estrutura urbana da cidade do Mindelo, ao longo da história, com especial ênfase no período de 1969 a 2014 e o conteúdo dos principais instrumentos de planeamento que contribuíram para moldar a sua organização e propor contributos para uma proposta de estrutura urbana. Neste contexto, considera-se a cidade do Mindelo como parte inseparável da Ilha de S. Vicente em que se situa $(92,5 \%$ da população da ilha vive na cidade do Mindelo) podendo por isso ser considerada uma "cidade-ilha".

Uma análise breve da evolução histórica da cidade permite assinalar os momentos mais importantes que marcaram o seu crescimento populacional. Uma caracterização biofísica sucinta da ilha de S. Vicente, a par da análise dos diversos instrumentos urbanísticos que moldaram a evolução da cidade do Mindelo, permitem identificar os elementos estruturantes que condicionaram a ocupação humana da ilha.

Por fim procura-se dar um contributo para aquilo que designamos por uma proposta de estrutura de ordenamento para a cidade-ilha de Mindelo-S. Vicente, elaborada claramente em contexto académico, na sequência da elaboração duma tese de mestrado (ANDRADE,2016), onde se incluem análises justificativas mais detalhadas. 


\subsection{Metodologia}

Os métodos de trabalho usados neste estudo são essencialmente analíticos tirando partido da informação disponível nas fontes bibliográficas tradicionais, nomeadamente Websites e Fontes Cartográficas Oficiais, Centros de Documentação, Bibliotecas, Repositórios de Dissertações, etc. Na caracterização geográfica e biofísica recorre-se a um modelo digital de terreno da ilha de S Vicente. A análise dos principais planos urbanísticos que condicionaram a estrutura urbana serve sobretudo para o mapeamento e identificação da mancha de ocupação urbana da cidade em 4 momentos temporais (1969, 1993, 2003, 2014). A avaliação da evolução da mancha urbana ao longo daqueles três períodos (1969-1993, 1993-2003, 2003-2014), foi feita com base nas cartas disponíveis: carta militar de 1969 do Instituto cartográfico do Exército Português; mapa de ocupação da cidade do Mindelo em 1993, resultante do ortofotomapa de 1993, elaborado pela empresa holandesa KLM tendo servido de base a elaboração do PDM/PDU de 1994/95; Ortofotomapa de 2003 elaborado pela empresa Municípia e o Ortofotomapa de 2014 trabalhado a partir de Imagens atualizadas do Google Earth. A identificação dos principais elementos estruturantes é esboçada manualmente e posteriormente georreferenciada e desenhada recorrendo ao software Arcgis (ESRI, Co).

\section{Apontamentos históricos e caracterização da Ilha de S. Vicente}

\subsection{História da Evolução Urbana do Mindelo}

A história da cidade do Mindelo pode ser dividida em três grandes períodos: sua fundação (1794-1850); seu crescimento, crise e estagnação (1850-1960) e a sua transformação (1960dias atuais)

No 1 o período de "Fundação", a cidade do Mindelo é criada a partir de um povoamento oficial na ilha de S. Vicente, entre 1794 e 1797, tendo tido vários nomes ao longo da história, desde "Povoação Dom Rodrigo" em 1798, "Povoação Leopoldina" em 1819 e finalmente “Povoação do Mindelo", em 1838, devido a várias crises que ocorreram nos primórdios de 
sua ocupação humana, marcada pelas secas cíclicas que sempre afetaram as ilhas de Cabo Verde. Nesse período a ilha de S. Vicente passou por várias oscilações demográficas, tendo justificado novos repovoamentos e recomeços.

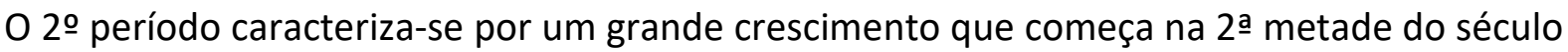
XIX, fruto do aproveitamento para exploração industrial do Porto Grande em 1850, com o propósito de servir de entreposto comercial de abastecimento de carvão dos navios que circulavam pelo Atlântico. A ilha atingiu o seu auge no fim do séc. XIX, quando o Mindelo se tornou a principal cidade do arquipélago, em resultado do desenvolvimento gerado pelo aproveitamento do seu amplo e abrigado porto que chegou a ser um dos mais frequentados do Atlântico médio. Esse desenvolvimento justificou a sua elevação a categoria de vila em 1858 e de cidade em 1879. A cidade cresceu e o núcleo central configurou-se com base numa estrutura marcada pelo urbanismo tradicional, baseada em quarteirões retangulares estreitos. Mas a parte que mais cresceu nesse período foi a zona portuária com as grandes ocupações do litoral pelas companhias carvoeiras inglesas.

No século XX a cidade do Mindelo enfrentou uma crise resultante das mudanças tecnológicas que introduziram alteração na utilização do combustível pelos navios que substituíram o carvão pelo petróleo. O Porto Grande não acompanhou essa mudança, pois não foram criadas as infraestruturas portuárias necessárias à sua modernização, levando a uma perda de importância relativa com os portos concorrentes de Dakar, Las Palmas e Tenerife.

O 3ำ período é caracterizado pela transformação do núcleo urbano existente e pelo colmatar da estrutura desordenada da cidade. O período 1959-60 tinha sido crucial para a política colonial e política externa portuguesa, quando o Governo era ainda liderado por Salazar. Segundo (SILVA 1995:7)“A descolonização tornara-se irreversível (...) mas o Governo mantinha-se intransigente". Talvez por isso o Estado Português apostava num forte investimento na transformação da cidade do Mindelo, com a construção do aeroporto em 1960, de um novo cais acostável em 1961, e com a implementação de novos Planos de Urbanização para toda a cidade, que visavam a incorporação dos bairros periféricos na estrutura da cidade. No Mindelo observava-se uma franca modernização, concretizada através de planos parcelares e pela reabilitação das áreas do centro histórico, que tinham 
sido abandonadas pelas companhias carvoeiras. A transformação e o crescimento da cidade continuaram, no período pós independência, a seguir a 1975, em bom ritmo, mas sem acompanhamento de planos eficazes que pudessem controlar a expansão urbana.

\subsection{Caracterização biofísica da Ilha de S. Vicente}

A cidade do Mindelo localiza-se a noroeste da llha de São Vicente, uma das dez ilhas do arquipélago de Cabo Verde, situado a 450 km da costa Ocidental Africana. Desenvolve-se na parte menos acidentada da ilha de S. Vicente, sendo limitada pela baía do Porto Grande e por colinas mais ou menos pronunciadas (Fig.1). A ilha de S. Vicente tem uma superfície de $227 \mathrm{~km}^{2}$, representando 5,6\% da superfície do arquipélago (4033 km²).

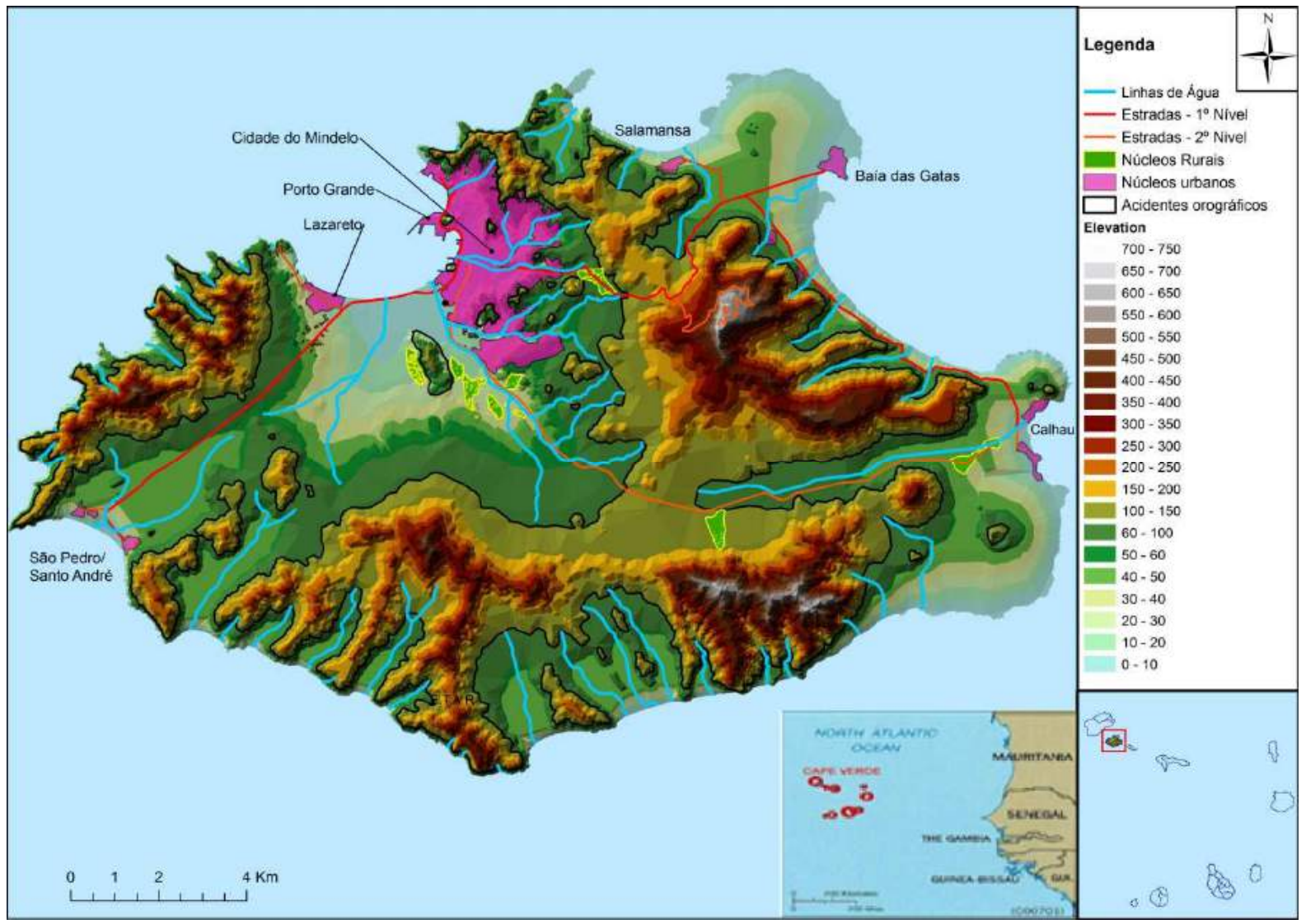

Fig. 1 - Localização geográfica da Cidade do Mindelo (ANDRADE,2016:18)

A Ilha de S. Vicente apresenta cadeias montanhosas com algum significado, correspondendo aos restos do antigo aparelho vulcânico que deu origem à ilha. Contudo a cidade do Mindelo localiza-se em áreas com declives baixos (0-4\%) e muito raras vezes em declives ainda 
moderadamente baixos (4-12\%), apesar da recente ocupação das encostas no sentido Nordeste e Sudeste, onde tende a expandir para declives mais elevados (12-25\%). Os maiores declives (25-58\%) da ilha de S. Vicente, registam-se já fora da cidade do Mindelo, nas 4 maiores cadeias de montanhas, nomeadamente no Monte Verde (750 m de altitude), Madeiral (699m), Tope de Caixa (535m) e Monte Cara (480m).

A localização do Mindelo também é fruto do aproveitamento das boas condições de exposição solar (ANDRADE, 2016:21) na parte norte da caldeira vulcânica do Mindelo, assim como da sua posição em relação à baía do Porto Grande, protegida dos ventos do nordeste pelas colinas do norte da ilha. Foi-se expandindo em direção a zonas mais planas e contornando os pequenos vales encaixados da parte norte da mesma caldeira vulcânica. Por outro lado os demais núcleos urbanos da ilha de S. Vicente localizam-se em áreas do litoral junto a enseadas ou baías mais ou menos abrigadas, sendo de destacar os núcleos urbanos de S. Pedro, Salamansa, Baía das Gatas e Calhau e alguns núcleos rurais dispersos pelo interior da ilha.

\subsection{Caracterização demográfica}

S. Vicente, embora seja uma ilha de povoamento tardio, teve um crescimento demográfico linear quando comparada com a evolução da população de Cabo Verde. O arquipélago sofreu ao longo da sua história várias oscilações, ocorrendo mesmo períodos de grande quebra demográfica, coincidindo em muitos casos com os períodos de seca prolongada, particularmente a década de 1940, quando se registou considerável diminuição populacional (Gráfico 1).

Em termos percentuais a população da llha de S. Vicente, em 1950 representava 13\% da população de Cabo Verde, tratando-se nessa altura da 3 a ilha em termos populacionais. No último censo de 2010 representava 15,5\% da População de Cabo Verde, passando a 2a ilha do Arquipélago em termos populacionais.

A taxa média anual de crescimento populacional da ilha de $\mathrm{S}$. Vicente foi de $1,33 \%$ na última década, ligeiramente superior à média de crescimento anual de Cabo Verde (1,31\%). Apesar 
da tendência ser de estagnação, S. Vicente é dos poucos municípios com um crescimento superior à média do país (INECV,2010:12)

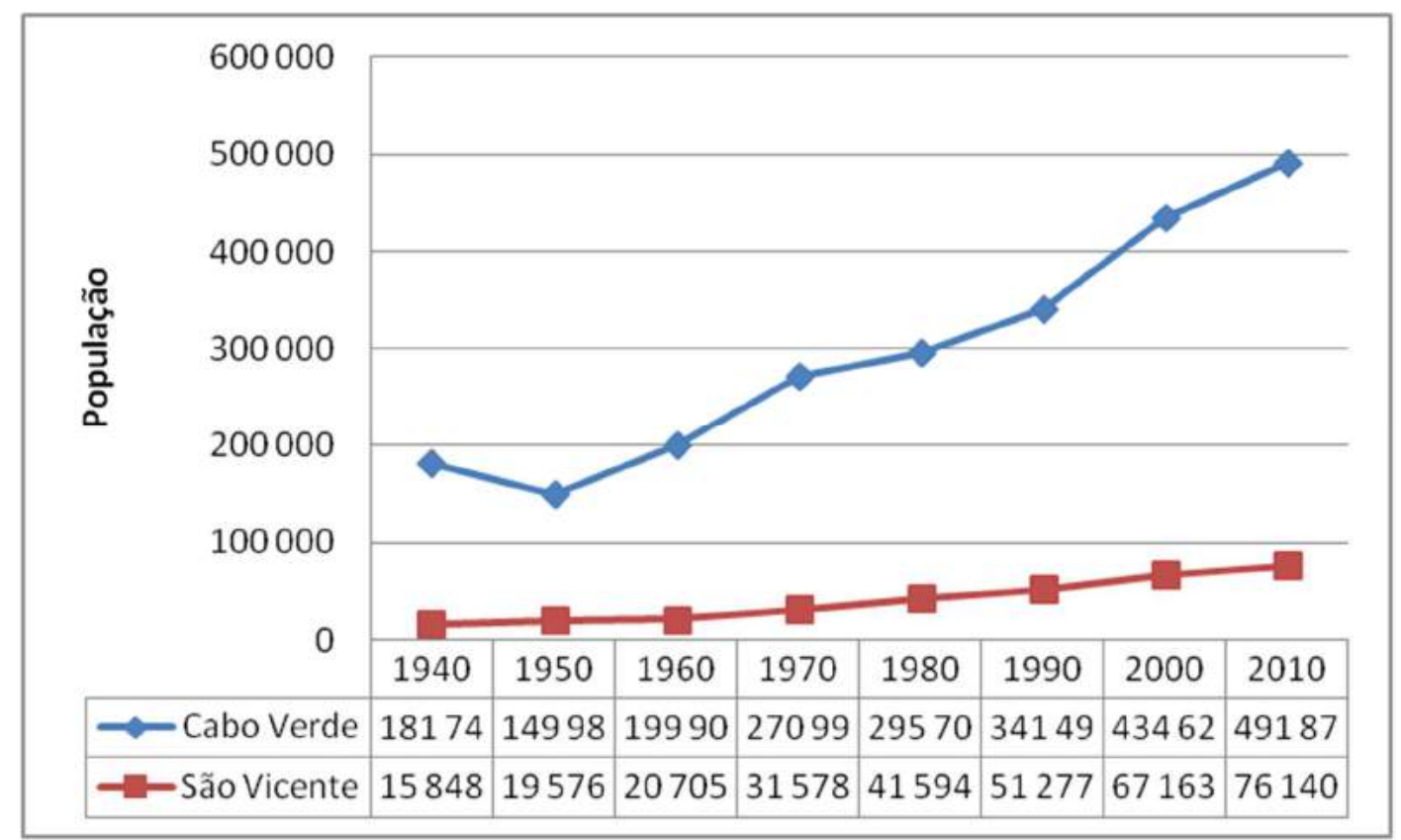

Gráfico 1 - Evolução da População de Cabo Verde e de S. Vicente (1940-2010) (INECV,2016)

\subsection{Caracterização Económica}

Em termos económicos, o movimento marítimo de longo curso que aportava ao Porto Grande do Mindelo, representou sempre o grosso das receitas da llha de São Vicente e fazia com que esta fosse uma das ilhas que mais contribuía para os cofres da província de Cabo Verde, da 2 ${ }^{a}$ metade do século XIX até meados do século XX.

No início do século XX, o Porto Grande registou uma queda do movimento portuário devido à mudança gradual efetuada na utilização do petróleo em substituição do carvão. Nas primeiras décadas pós 1a guerra mundial, em virtude da depressão económica de 1929, a crise acentuou-se, tendo a navegação internacional sido canalizada para outros portos, como o de Las Palmas (Canárias) e Dakar, onde os preços de abastecimento de combustíveis eram mais baixos. Deste modo, o Porto Grande deixou de ser o principal porto do Atlântico, apesar das suas boas condições naturais.

Contudo, no cenário cabo-verdiano, a ilha de S. Vicente continuou, através do seu Porto Grande, a representar a principal fonte de receitas para a Província de Cabo Verde. Em 1925 as receitas de S. Vicente representavam 33 \% das receitas municipais do Arquipélago, quando a ilha ainda só representava $9 \%$ da população do arquipélago; em 1930, logo a seguir ao despoletar da maior crise económica do século XX, a economia de S. Vicente ainda 
representava $30 \%$ do total das receitas de Cabo Verde, diminuindo este valor para $28 \%$ em 1935 (PAPINI, 1984:80).

No período pós 2a guerra mundial as autoridades portuguesas, em certa medida para justificar a manutenção das suas colónias, procuravam fazer aí alguns investimentos relevantes. Em 1961 o Porto Grande do Mindelo foi dotado de um cais acostável que pudesse concorrer com outros portos do Atlântico. Mas neste período o grosso da navegação internacional do Atlântico já não passava pelo Porto Grande e a economia de S. Vicente foi perdendo a sua hegemonia.

Atualmente, apesar de continuar a crescer em termos populacionais, representando $15,5 \%$ da população cabo-verdiana, a ilha de S. Vicente registava em 2015 uma das maiores taxas de desemprego de Cabo Verde (14,8\%) (INECV,2015a:52), acima da média nacional (10,7\%), contribuindo com pouco mais do que $15 \%$ para o PIB de Cabo Verde, valor bastante inferior em relação a sua contribuição que ocorreu no passado.

Apesar dos níveis de desemprego, S. Vicente é ainda a 2a ilha em termos de contribuição para o PIB nacional conforme análise feita pelo INECV sobre a evolução e distribuição do PIB de Cabo Verde por ilhas (gráfico 2) no período 2007 a 2012 (INECV, 2015b:37), valor que é consentâneo com o peso populacional da ilha (15,5\% da população de Cabo Verde).

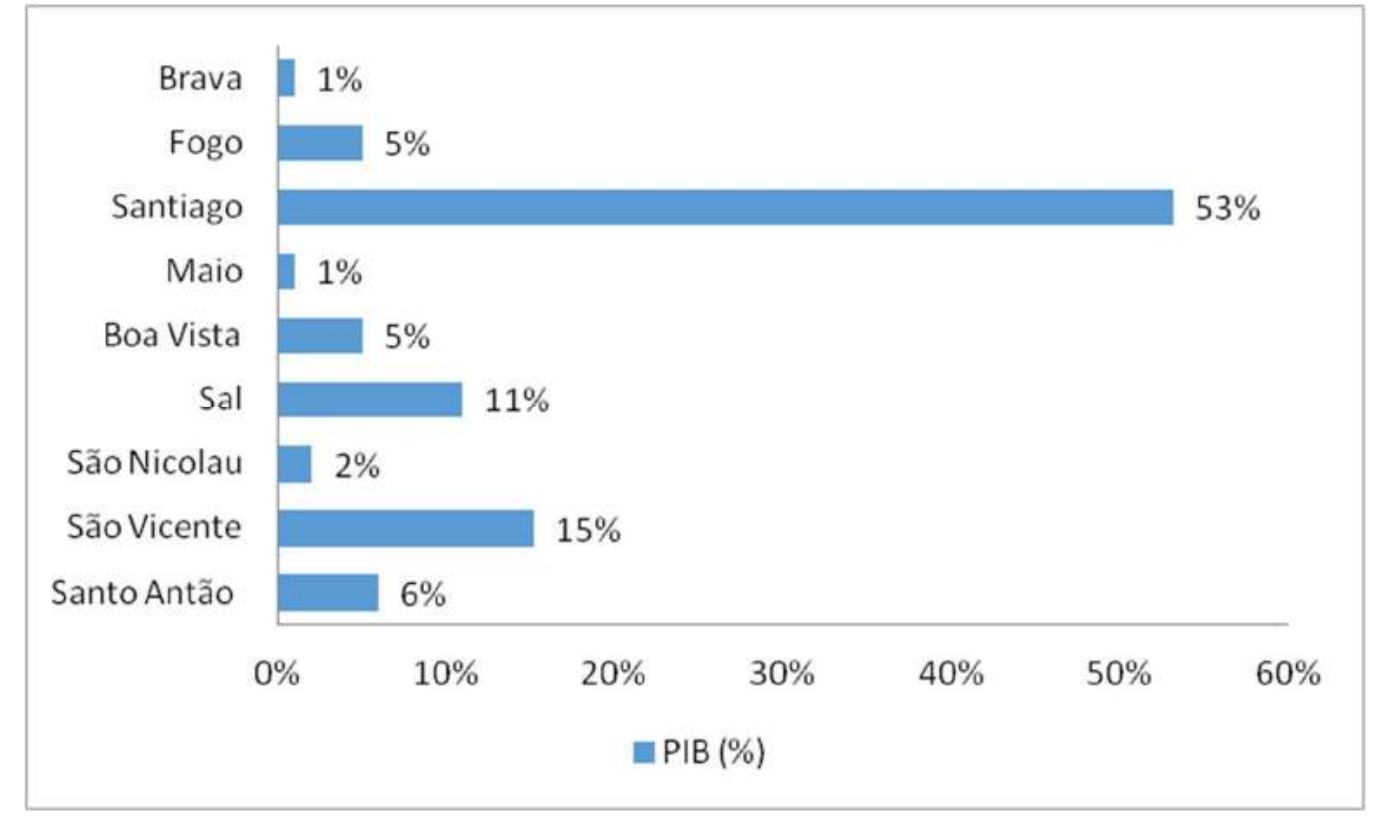

Gráfico 2 - Estrutura do PIB de Cabo Verde por Ilhas em 2012 (INECV,2015b:37)

As atividades económicas mais presentes em S. Vicente continuam a ser as do sector terciário, seguido do industrial, que é uma forte aposta mais recente através do investimento no parque industrial do Lazareto, que poderá atrair investimentos nos 
próximos anos em consonância com a abertura do aeroporto Cesária Évora, em 2009, a voos internacionais.

A debilidade do setor primário (nomeadamente devido à topografia, à debilidade dos solos e à escassez de água), faz com que seja uma ilha essencialmente urbana, apresentando uma grande concentração populacional na cidade do Mindelo (92,5\% da sua população) e valores residuais de população nos demais núcleos urbanos e rurais. Assim podemos afirmar que a ilha de S. Vicente é uma ilha-cidade, pois todo o seu desenvolvimento depende da sua principal cidade.

\section{Planeamento e evolução da estrutura da cidade do Mindelo}

A evolução da estrutura urbana da cidade foi essencialmente suportada pelos diversos instrumentos urbanísticos elaborados para a cidade do Mindelo ao longo da última fase da sua história (1960-2015), com especial ênfase nos planos de urbanização da década de sessenta.

\subsection{Os planos para a cidade do Mindelo e ilha de S. Vicente}

Segundo (FERNANDES,2016:90-91), no final dos anos 50 na cidade do Mindelo distinguia-se duas áreas de natureza muito distinta: "uma delas era caracterizada pela estrutura fundacional da cidade, determinada pela condição portuária do sítio e pela matriz regular e ortogonal do traçado urbano (...) e na envolvência do núcleo mais antigo, inclusive nas pendentes dos morros, dispunham-se os bairros residenciais mais recentes onde predominavam construções precárias e a ausência das infraestruturas mais elementares de abastecimento, de saneamento ou mesmo de circulação". Com vista a adequar a cidade do Mindelo à sua condição de principal porto do arquipélago, entre 1959-1974, período de maior atividade do Gabinete de Urbanização Colonial, foram elaborados três Planos de Urbanização e uma série de planos parciais e parcelares para o Mindelo (gráfico 3): o primeiro, designado de Plano de Urbanização do Mindelo (Esboceto) de 1959 (Fig.2) serviu de base à elaboração dos demais planos, o Plano Diretor-Base de 1960 (Fig.3) e o Plano Diretor de 1969 (Fig.4).

Estes planos de urbanização tinham dois objetivos principais para a cidade do Mindelo: 
-fomentar a intervenção no tecido urbano pré-existente, levando à transformação do já existente (através da renovação urbana da área construída) e de toda a frente litoral com vista a reestruturar a cidade em torno da sua ampla baía; - fomentar a expansão urbana, através da criação de infraestruturas viárias necessárias a ligação dos vários núcleos periféricos com o núcleo mais antigo, que seriam materializados através dos vários planos parcelares que promoveram a consolidação do tecido urbano da cidade do Mindelo.

Em consequência disso, a cidade atual apresenta uma certa continuidade entre os diversos bairros que constituem a área englobada pelos planos urbanísticos, em claro contraste com a situação de dispersão urbana existente na década de sessenta, o que demonstra a importância que os mesmos tiveram na estruturação da cidade do Mindelo.

Ao longo da década de sessenta e princípios da década de setenta, foram também elaborados vários planos parcelares para a cidade do Mindelo que concretizaram as opções estratégicas dos planos diretores de 1960 e de 1969 . Após a independência foi elaborado o Plano Diretor do Mindelo de 1979 (PFEIFFER,1979), o Plano de Urbanização de 1995 (DGOT,1995) em consonância com o Plano Diretor Municipal de 1994 (DGOT,1995), que permanece em vigor, apesar de ter ultrapassado o seu horizonte temporal no ano de 2007.

Entretanto em 2011, foi lançado novo Plano Diretor Municipal (Fig.6) que não foi aprovado pelo governo devido a divergências políticas entre o município e o governo central, relacionadas com a localização das principais infraestruturas da ilha.

Em 2012 começou a ser elaborado o EROT-SV, Esquema Regional de Ordenamento do Território da Ilha de S. Vicente (DGOTDU,2012), tendo sido aprovado em 2014. ${ }^{1}$

Com isso, criaram-se as condições para a revisão do Plano Diretor Municipal e a elaboração de novo Plano de Urbanização para a cidade, por forma a garantir um controle mais efetivo da expansão urbana.

\footnotetext{
${ }^{1}$ Esquema Regional de Ordenamento do Território de S. Vicente- EROT- S. Vicente - Publicado na IMPRENSA NACIONAL DE CABO VERDE (INCV, 2014) - I Série - № 2 do B. O. da República de Cabo Verde- resolução n.o 4/2014 de 8 de Janeiro- http://extwprlegs1.fao.org/docs/pdf/cvi130663.pdf.

EROT- É o instrumento de planeamento que a nível regional estabelece o quadro espacial das atuações com impacto na organização do território, estando consagrado na Lei de Bases do Ordenamento do Território e Planeamento Urbanístico de Cabo Verde, onde é considerado como um Instrumento de ordenamento e desenvolvimento territorial, de natureza estratégica e vinculativo das entidades públicas- Publicado na IMPRENSA NACIONAL DE CABO VERDE (INCV, 2006), I Série-no 7- Decreto Legislativo no1/2006 de 13 de Fevereiro http://www.sdtibm.cv/documentos/BO/bo I 13-02-2006 7.pdf
} 


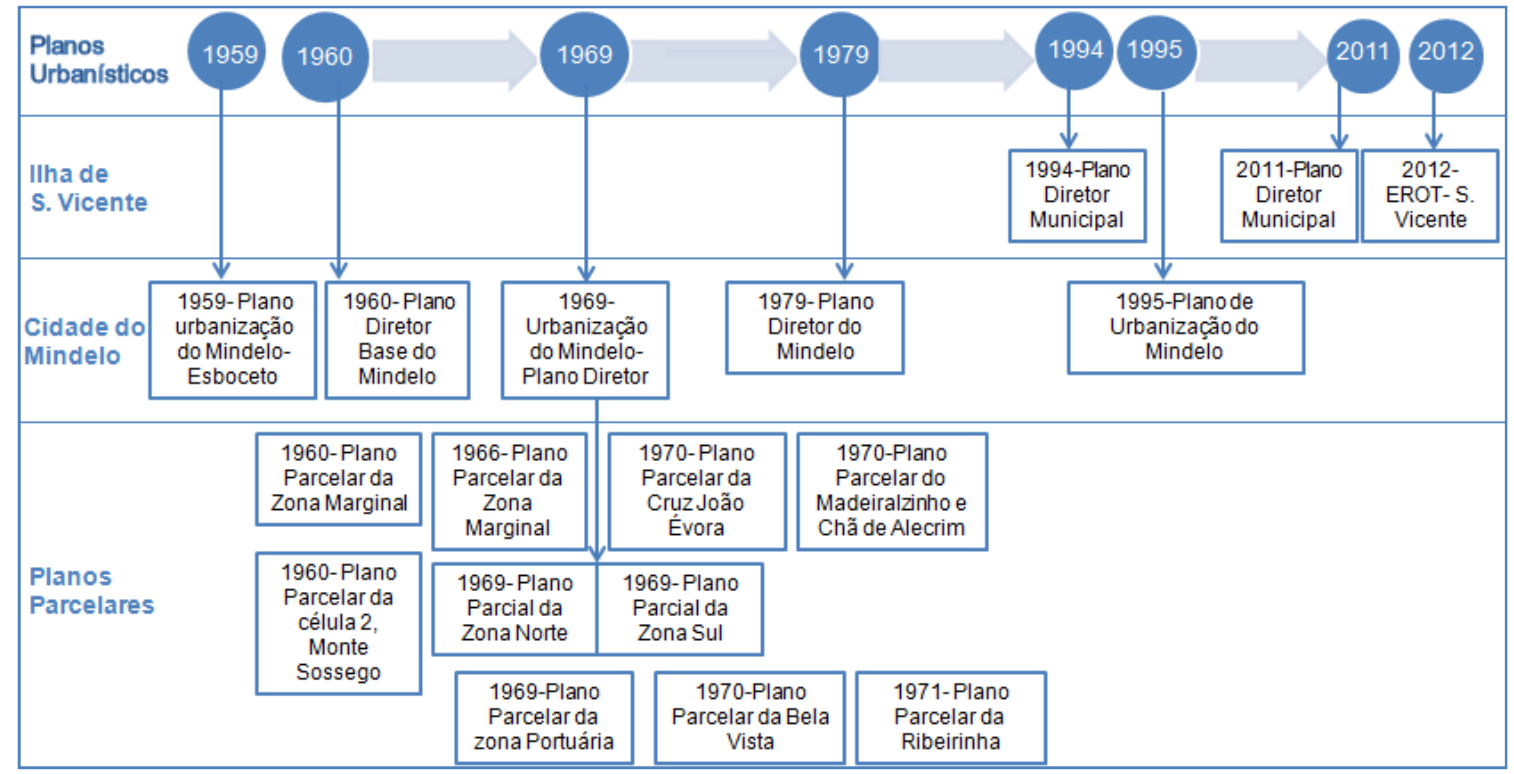

Gráfico 3: Régua cronológica dos planos elaborados para Mindelo-S. Vicente (ANDRADE,2016:33)

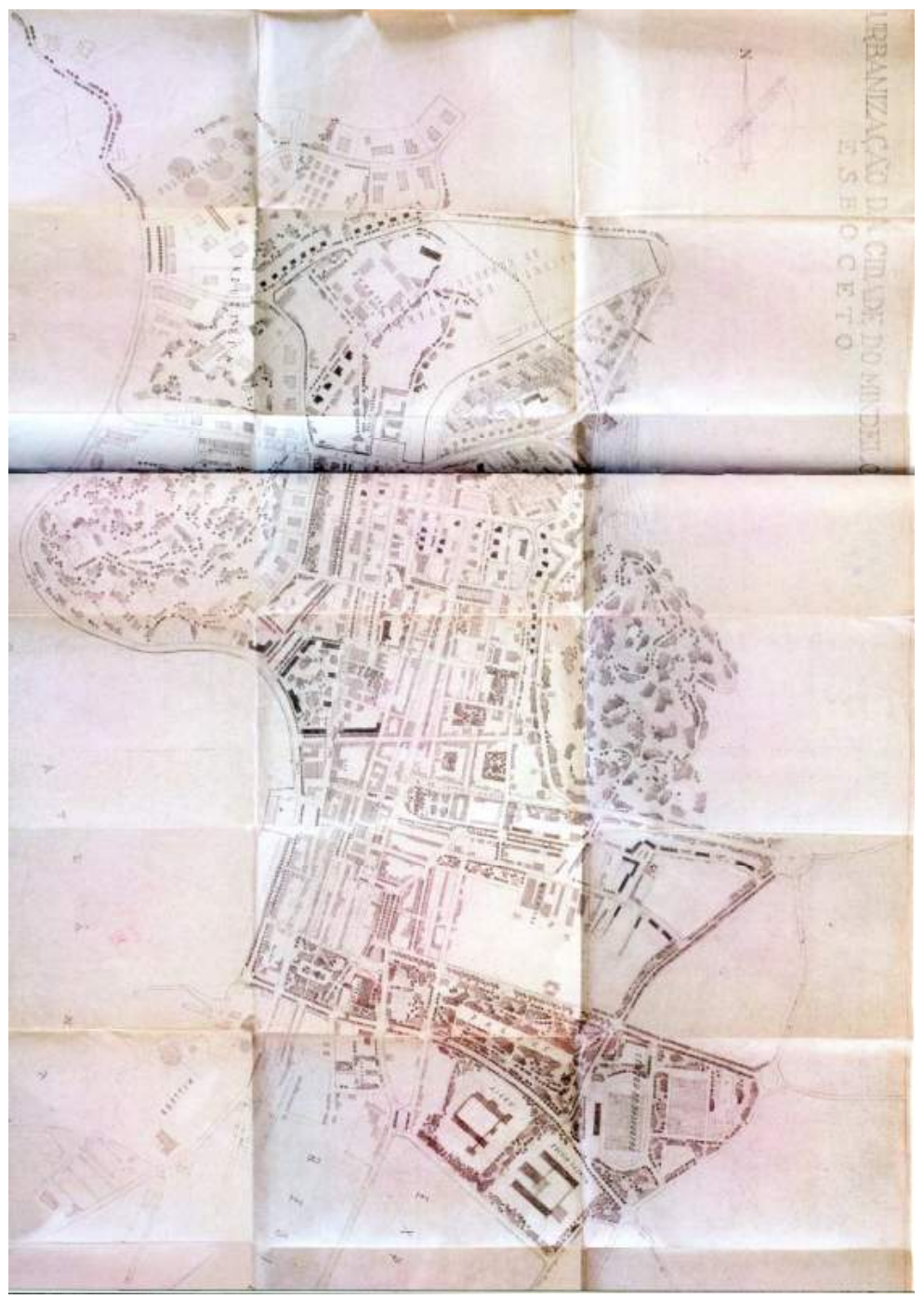

Fig. 2: Plano de urbanização da cidade do Mindelo-Esboceto (AGUIAR,1959) 


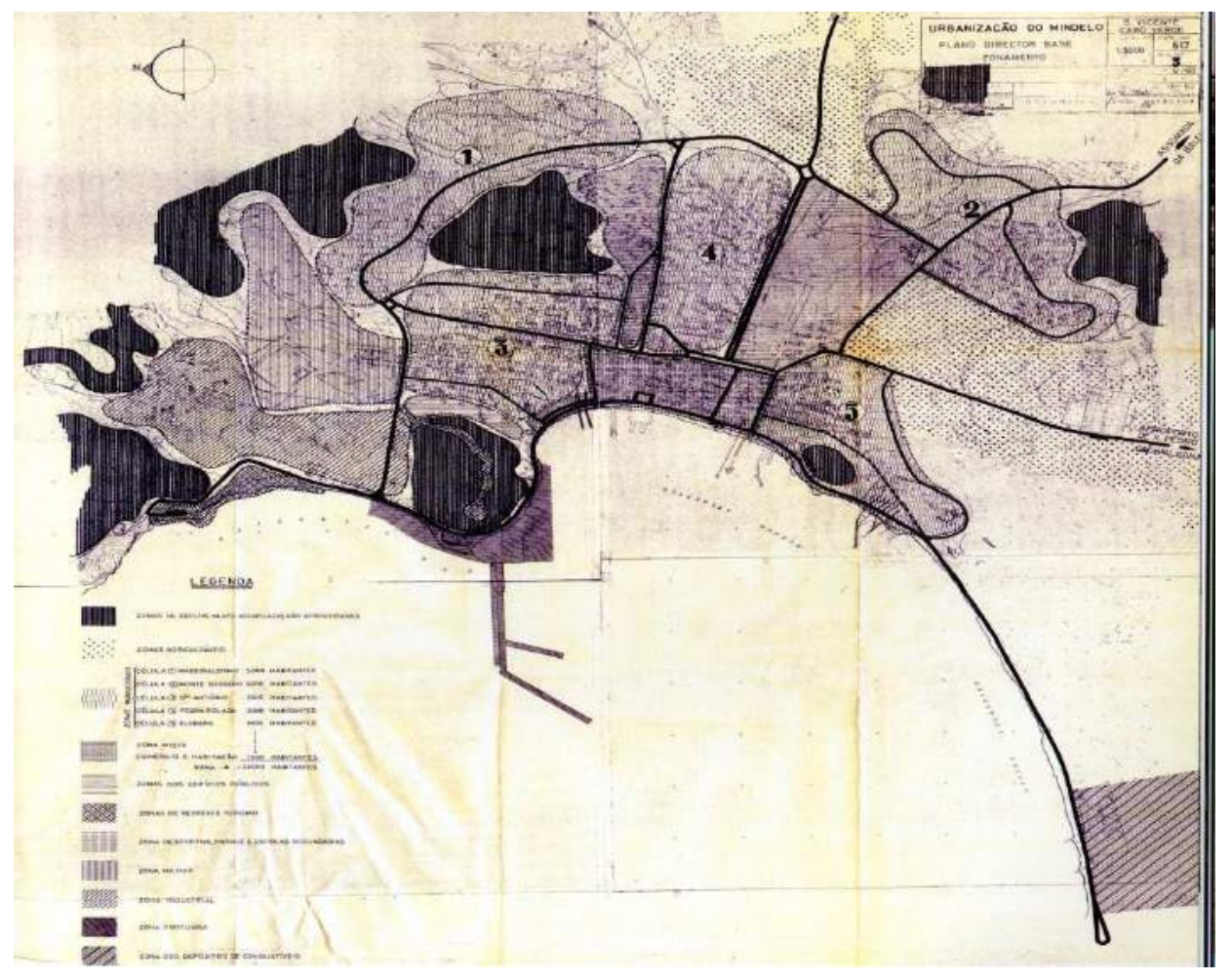

Fig.3: Plano Director Base (AMORIM,1960)

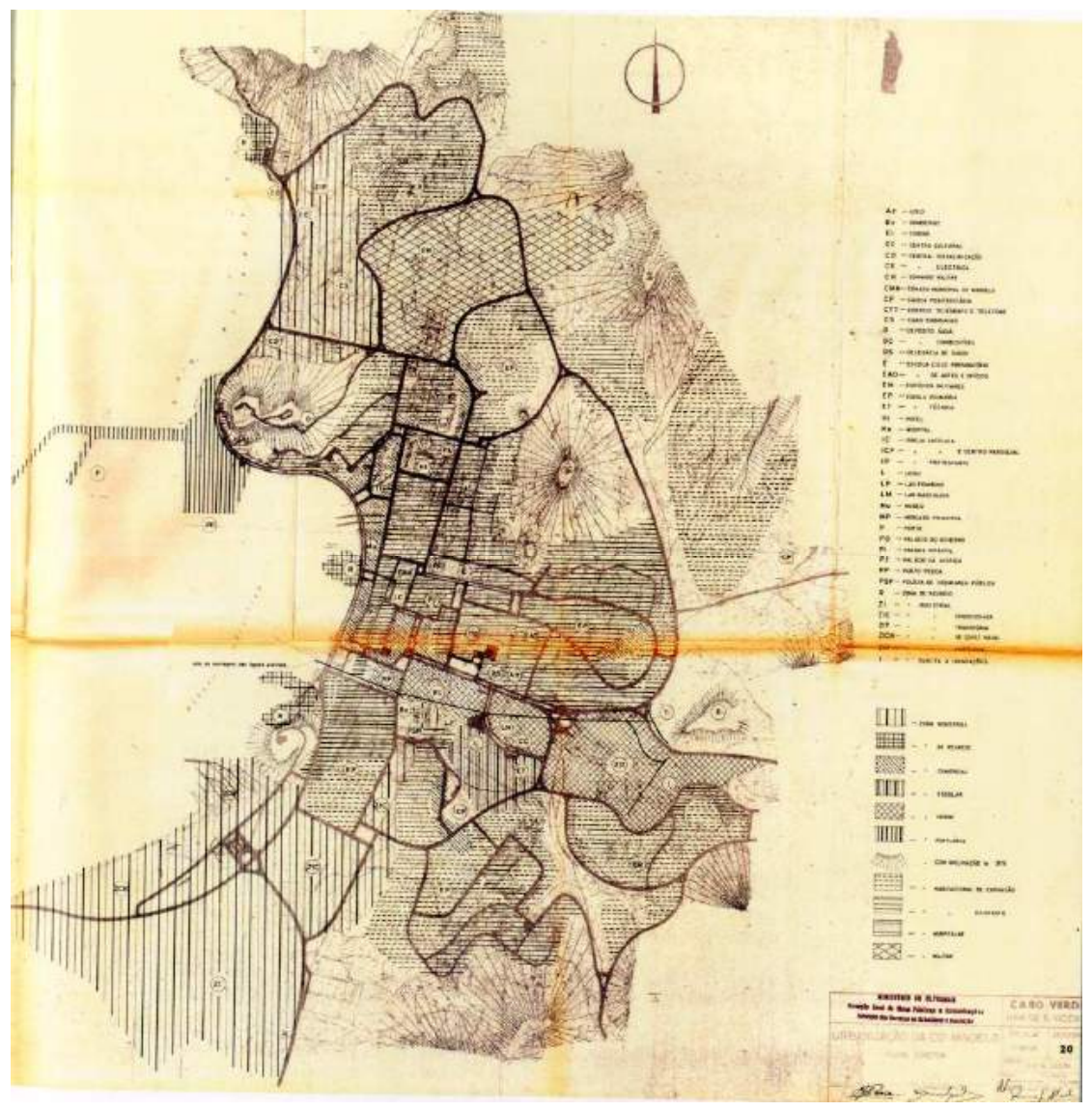

Fig. 4: Plano Director de 1969 (CÁRIA,1969) 


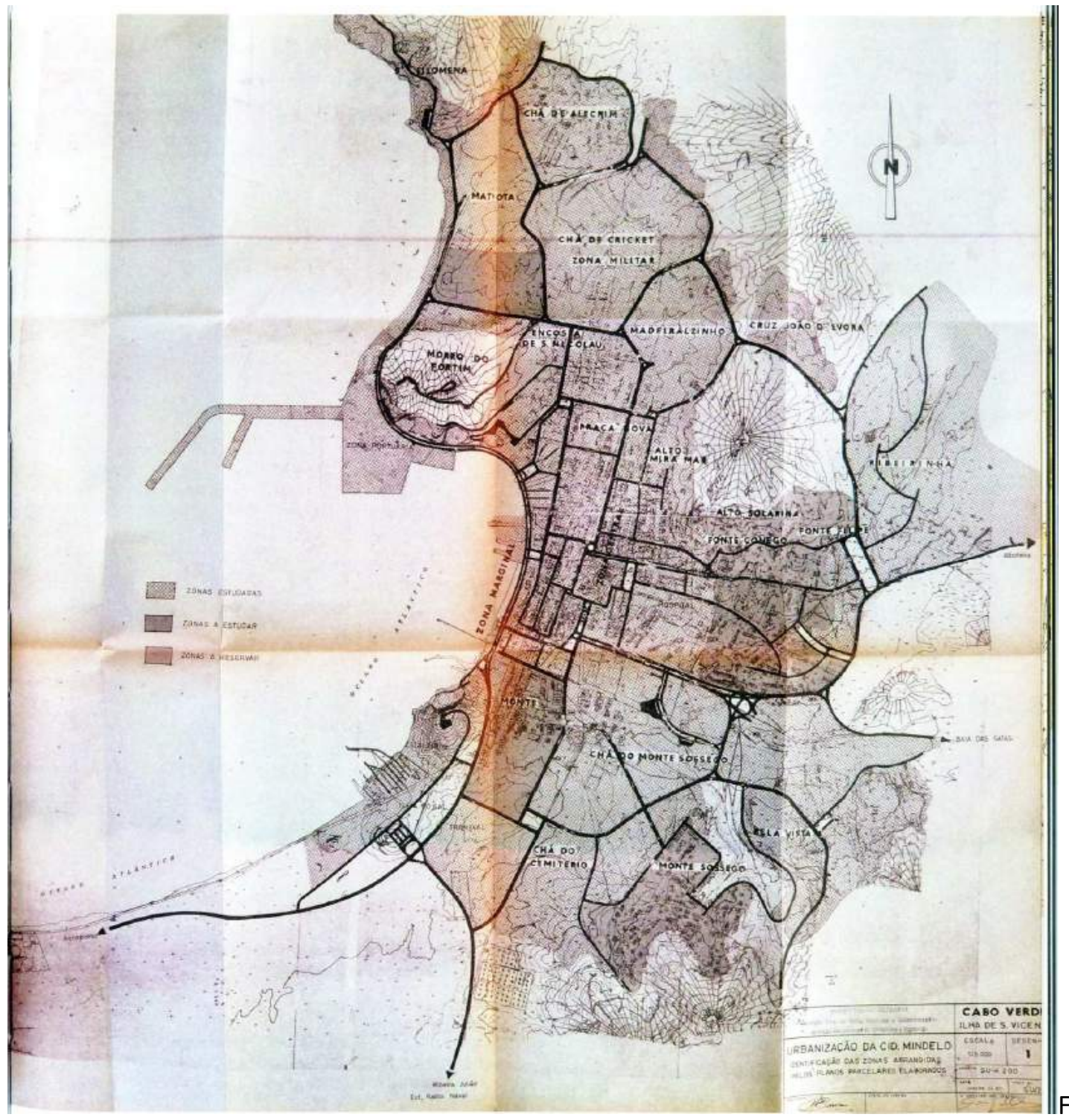

Planos parcelares (CÁRIA, 1971)

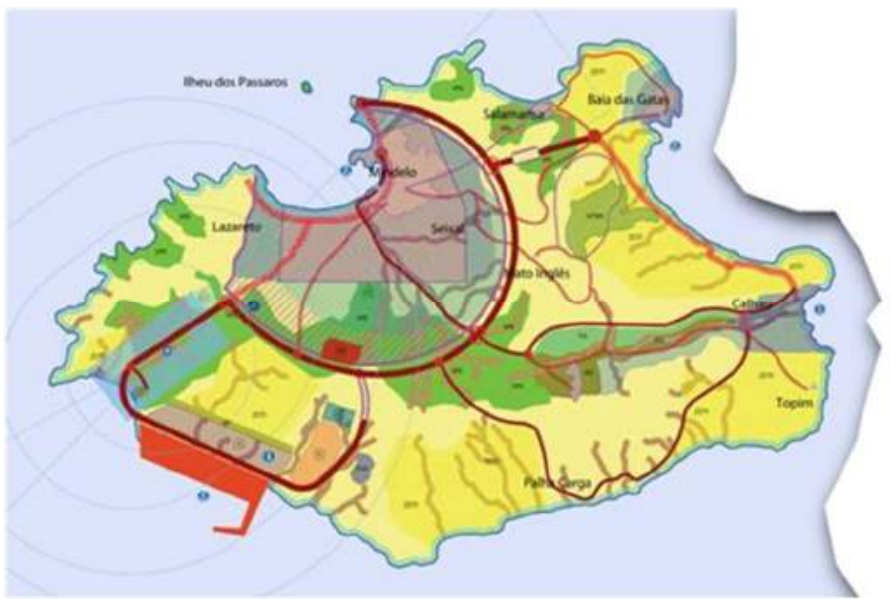

\section{PLANO DIRECTOR MUNICIPAL DA ILHA DE SÄO VICENTE}

Valorizando as Pessoas, 0 Ambiente e a Baía do Porto Grande numa perspectiva de Sustentabilidade Económica

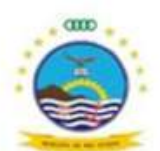

Câmara Municipal de São Vicente

Fig.6: Modelo Territorial do Plano Diretor Municipal da Ilha de S. Vicente (CMSV,2011:1) 


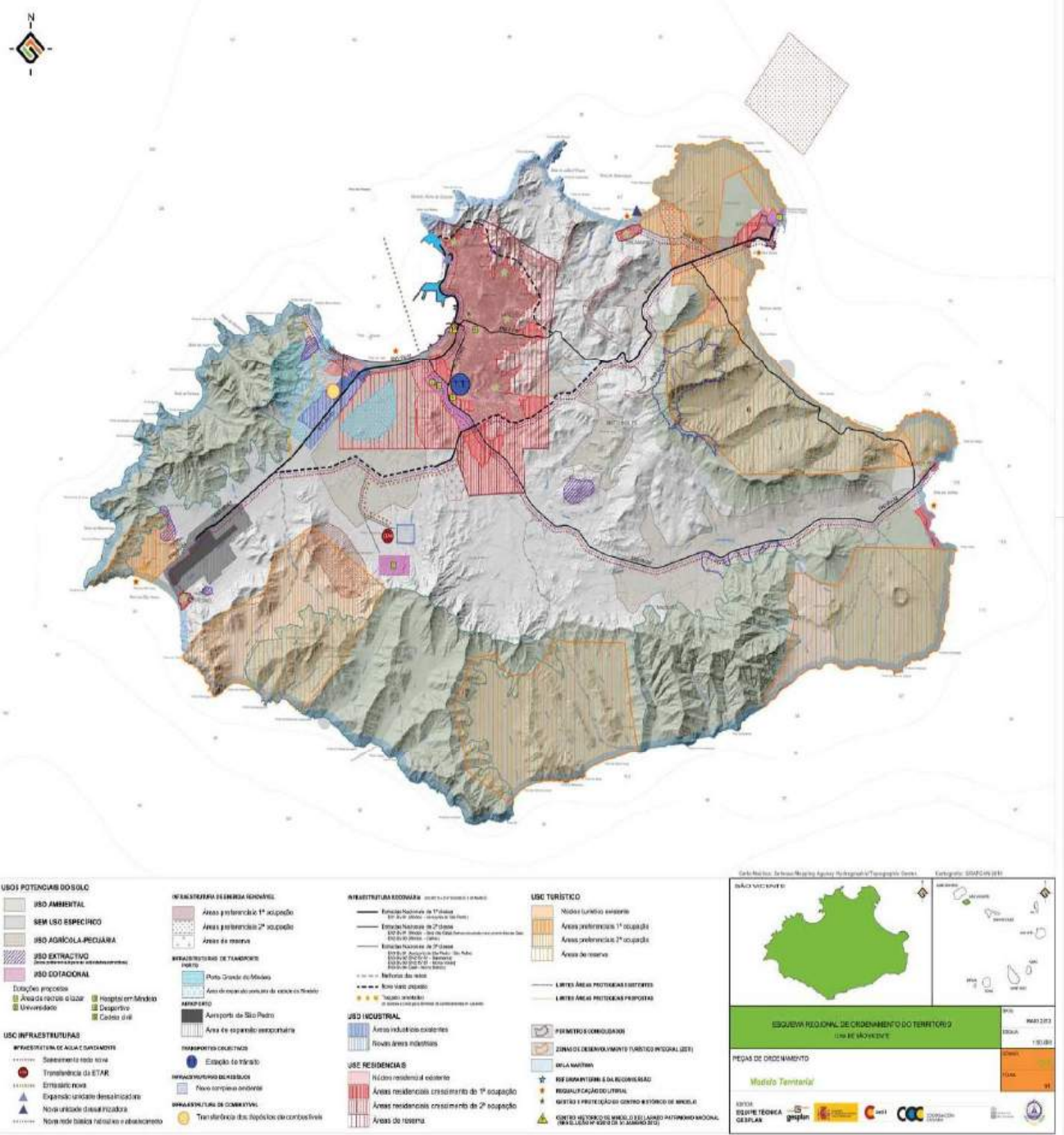

Fig.7: Modelo Territorial de Ordenamento de S. Vicente (INCV, 2014:81)

\subsection{Limites físicos e evolução da mancha urbana da cidade do Mindelo}

É curioso constatar que a cidade do Mindelo teve neste período três limites físicos, muito diferentes entre si, e que de alguma maneira espelham evidentes dificuldades de gestão do crescimento e ocupação urbana.

O 1 o limite a considerar é o do Perímetro Consolidado do Mindelo que abrange um polígono de $23,29 \mathrm{~km}^{2}$. Trata-se da área concedida pelo governo à Câmara Municipal de S. Vicente 
para sua jurisdição e consequente política de concessão de terrenos para loteamento. Constitui, contudo, uma delimitação muito grosseira e pouco rigorosa para efeito de licenciamento e de gestão da ocupação do solo devido ao facto de se tratar duma delimitação abstrata através de uma linha poligonal (Fig.8).

O 20 Limite (correspondente a uma área de $28,28 \mathrm{~km}^{2}$ ) é o Limite Administrativo usado pelo Governo de Cabo Verde ${ }^{2}$ para a delimitação dos limites administrativos de Cabo Verde. No mapa consultado a Cidade do Mindelo destaca-se da restante ilha, sendo de notar que a mesma se apresenta dividida em duas partes. A parte urbanizada encontra-se quase toda inserida na parte oriental da área circunscrita neste limite, sendo que a parte ocidental inclui o pequeno núcleo urbano de Lazareto, estendendo-se por uma área extensa e chegando às portas do Aeroporto, comprometendo a expansão ao mesmo, para além de englobar parte do Parque Florestal da Ribeira de Vinha. .

3o 0 3 limite (Perímetro Municipal) é o adotado pelo Município de São Vicente, sendo estipulado em sede de assembleia municipal em 2004. Constitui o limite mais extenso, englobando toda a caldeira vulcânica do Mindelo $\left(67 \mathrm{~km}^{2}\right)$. Apesar de corresponder bem ao conceito de 'unidade de paisagem' é claramente excessivo para efeitos de planeamento e gestão de uma cidade como o Mindelo.

Em face desta diversidade de limites urbanos entendeu-se ser útil propor um novo limite adaptado do limite administrativo, ajustando-se melhor à ideia de capacidade de carga do sistema, onde foram integrados as áreas urbanas e urbanizáveis, industriais e estrutura verde. Esta nova sugestão de delimitação da cidade do Mindelo para efeitos de planeamento e ordenamento, configura algo que pode servir de base à definição de um perímetro urbano futuro e que engloba uma área de $20,35 \mathrm{~km}^{2}$ (Fig.8).

O limite da cidade assim delineado assume-se como um limite funcional, na medida em que uma cidade deve conter nos seus limites todas as funcionalidades importantes à vivência de seus habitantes. Na definição do limite de uma cidade deve ter-se em conta a capacidade de carga de cada um dos seus elementos constituintes, onde deverão ser somadas as áreas residenciais existentes e de possível expansão, mas também as áreas industriais e de expansão industrial, assim como áreas para instalação de grandes equipamentos, espaços públicos e de lazer bem como áreas de espaços verdes que deverão ser incluídos na estrutura ecológica da cidade, para além das infra-estruturas básicas para a garantia das melhores condições de vida da população.

\footnotetext{
${ }^{2}$ Limites administrativos de Cabo Verde- http://arcgis.gov.cv/discusao/ (consultado em 20/02/2015)
} 


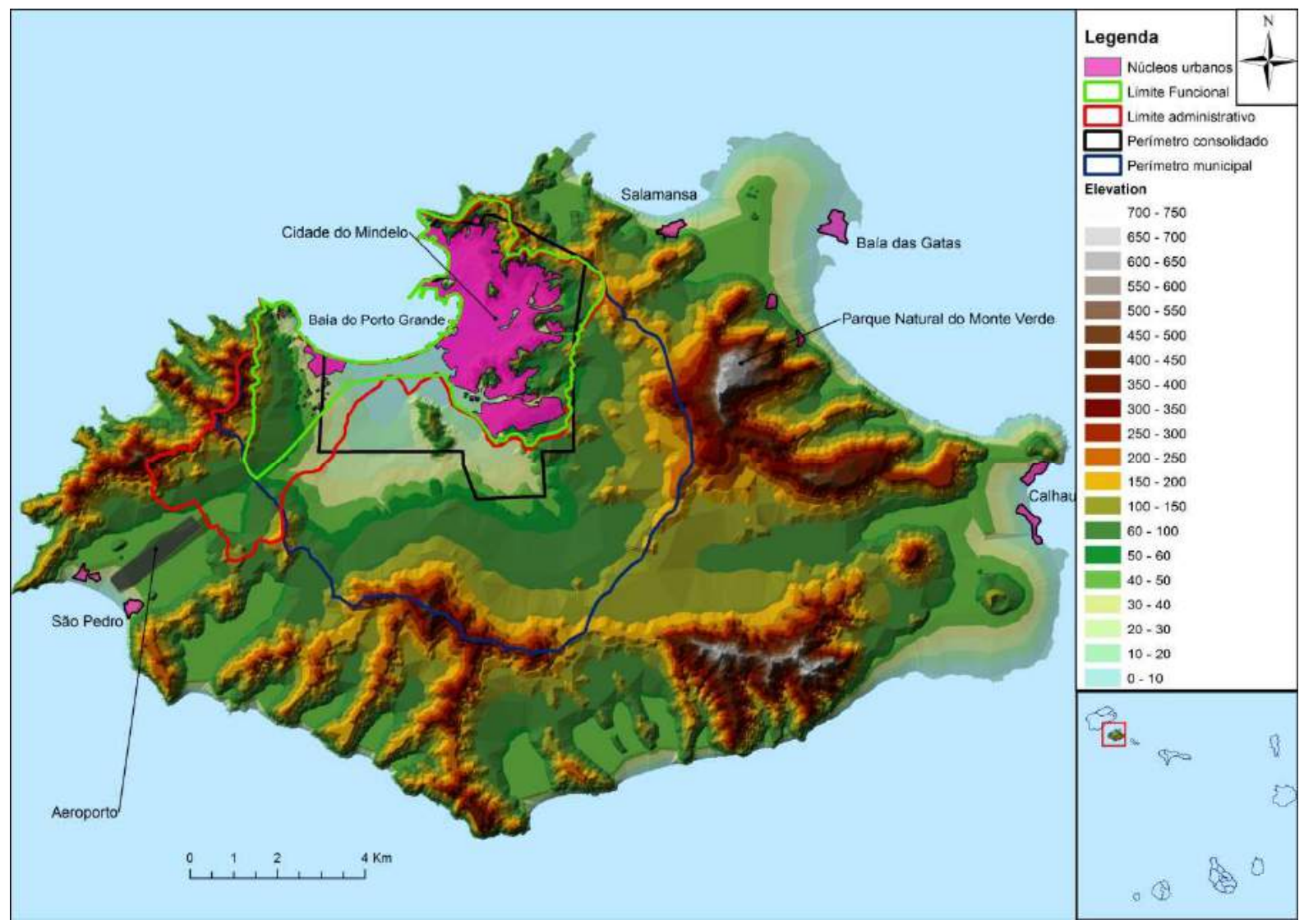

Fig.8 Delimitação da área urbana da cidade do Mindelo (ANDRADE,2016:44)

A análise da evolução da mancha urbana verificada na Cidade do Mindelo durante três períodos de tempo analisados - 1969-93, 1993-03, 2003-14 - permitiu constatar que a cidade tem tido um crescimento regular ao longo dos anos (tabela1). No 1o período registou-se um crescimento de 260 hectares em 24 anos o que perfaz uma média de 10,8 hectares por ano. No 2o período a área urbana aumentou 218 hectares em somente 10 anos o que equivale a um crescimento de $21,8 \%$ por ano, valor consideravelmente superior à média de crescimento no período anterior. Entre 2003 e 2014, a cidade cresceu 214 hectares, correspondendo a quase o mesmo valor, mas para um período ligeiramente superior (11 anos).

No cômputo geral, a cidade aumentou 692 hectares em 45 anos (1969-2014). O percentual de variação da área urbana ocupada foi na ordem dos $374 \%$, ou seja, a superfície da cidade do Mindelo aumentou 3,7 vezes em 45 anos, com a população a pouco mais do que duplicar em 40 anos (1970-2010), passando de 31578 hab. em 1970 para 70470 hab. (pop. da cidade do Mindelo), segundo dados do censo 2010 (INECV,2010:18).

Por outro lado, a densidade populacional da cidade do Mindelo diminuiu de 171 hab./hectare em 1970 para 80 hab./hectare em 2010 (cerca de metade). Isto significa que a 
cidade tem crescido segundo um modelo de ocupação horizontal, caracterizado por uma ocupação informal da periferia baseado na extensão de loteamentos para fins habitacionais com grandes défices de infraestruturação.

\begin{tabular}{|c|c|c|c|c|c|}
\hline $\begin{array}{c}\text { Período } \\
\text { em } \\
\text { Análise }\end{array}$ & $\begin{array}{c}\text { Variação } \\
\text { (hectares) }\end{array}$ & $\begin{array}{c}\text { Percentual } \\
\text { de variação } \\
(\%)\end{array}$ & $\begin{array}{c}\text { Intervalo } \\
\text { de tempo } \\
\text { (Anos) }\end{array}$ & $\begin{array}{c}\text { Crescimento } \\
\text { médio anual } \\
\text { (hectare/ano) }\end{array}$ & $\begin{array}{c}\text { Taxa de } \\
\text { cresc. médio } \\
\text { anual } \\
\text { (\%/Ano) }\end{array}$ \\
\hline $1969-1993$ & 185 a $445=260$ & 140 & 24 & 10,8 & 3,7 \\
\hline $1993-2003$ & 445 a $663=218$ & 49 & 10 & 21,8 & 4,1 \\
\hline $2003-2014$ & 663 a $877=214$ & 32 & 11 & 19,4 & 2,6 \\
\hline $1969-2014$ & 185 a $877=692$ & 374 & 45 & 15,4 & 3,5 \\
\hline
\end{tabular}

Tabela 1: Evolução da área urbana do Mindelo (1969-2014) (ANDRADE,2016:45)

Se compararmos a evolução da mancha urbana com a área ocupada atualmente $\left(8,77 \mathrm{~km}^{2}\right)$, constata-se que a cidade ocupava 1,85 km² em 1969 (apenas 21\% da área atual), em 1993 ocupava 4,45 km² ( $50 \%$ da área atual) e em 2003 ocupava 6,63 km2 (75\% da área atual já tinha sido ocupada). Em 1969 somente 9 \% da área da cidade circunscrita dentro do limite funcional da cidade $\left(20,35 \mathrm{~km}^{2}\right)$ estava ocupada, tendo este valor atingido os $21,9 \% \mathrm{em}$ 1993, 33\% em 2003 e 43\% em 2014. Naturalmente que a densidade da ocupação urbana não é uniforme. A cidade distribui-se por bairros com diversas dinâmicas de usos e com densidades de ocupação diferentes. Se por um lado os bairros do centro histórico se encontram densamente ocupados, outros mais periféricos apresentam baixas densidades de ocupação. A própria zona industrial apresenta ainda uma ocupação residual. Resulta portanto que a área atual ocupada pela cidade $\left(8,77 \mathrm{~km}^{2}\right)$ não atinge sequer metade dos $20,35 \mathrm{~km}^{2}$ do limite urbano antes referido - limite funcional.

A principal conclusão a retirar é que a cidade cresceu segundo um modelo de crescimento em mancha de óleo (Fig.9), contornando os principais acidentes orográficos. De realçar contudo que a ocupação apresenta uma estrutura relativamente compacta, com reduzidos focos de dispersão, excetuando o núcleo do Lazareto (a Poente da baía), com as suas especificidades próprias associadas a um carácter mais industrial da sua envolvente. De salientar também que a principal mancha de ocupação se continua a deter a Nascente da Baía, nas encostas montanhosas orientadas a Poente que vão caindo suavemente até ao oceano, parecendo confirmar o caracter protetor desta localização face aos ventos que emanam da costa de África. 


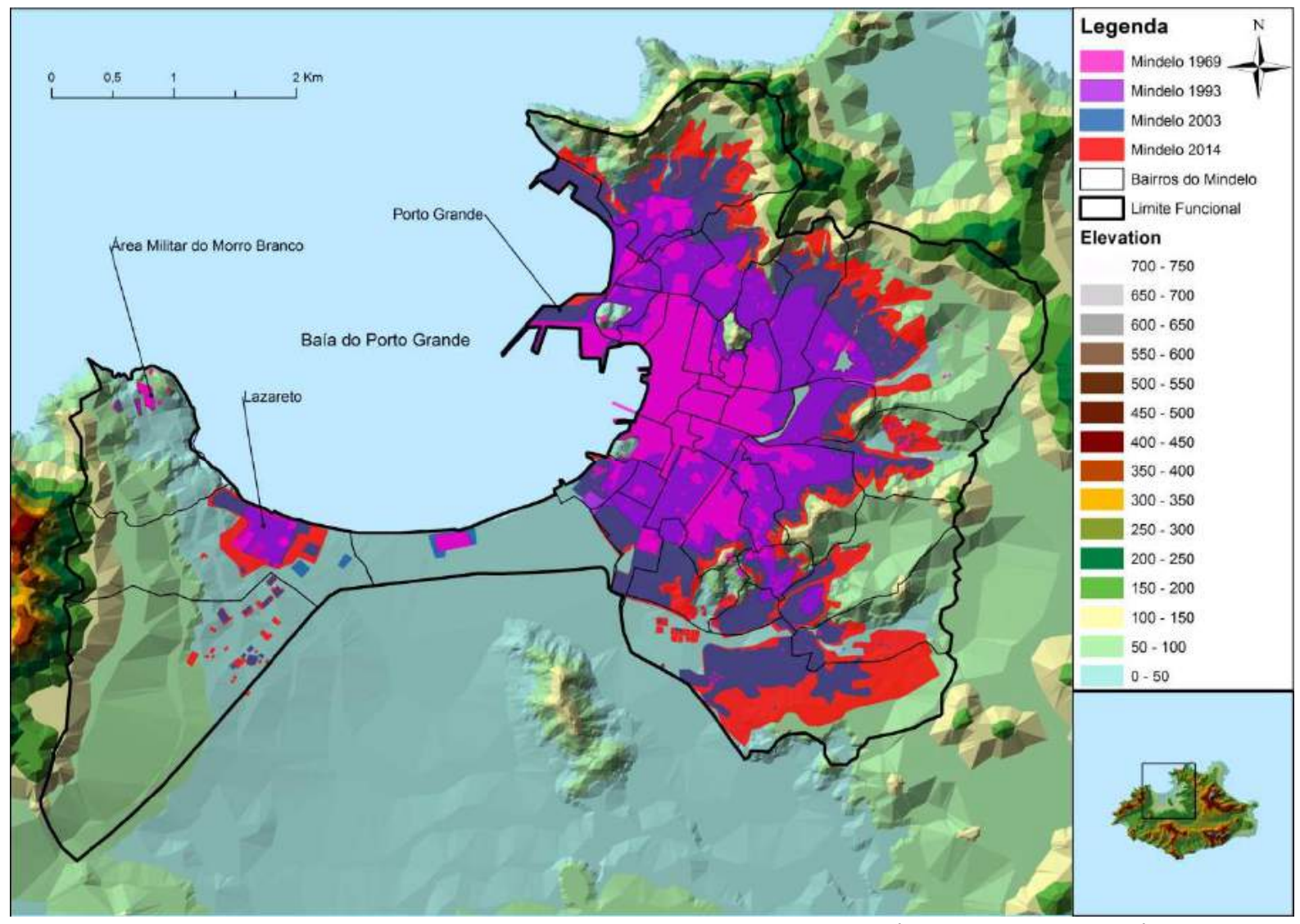

Fig. 9: Evolução da estrutura urbana da cidade do Mindelo (ANDRADE,2016:46)

\section{Contributos para um plano de estrutura}

\subsection{Cenários de desenvolvimento da cidade do Mindelo}

A análise histórica da ilha de S. Vicente e da expansão urbana da sua cidade permitiram formular três cenários exploratórios para o crescimento do Mindelo:

- um cenário tendencial, seguindo a continuação das tendências de crescimento urbano que se têm manifestado;

- um cenário voluntarista, seguindo as expetativas geradas por determinadas âncoras de desenvolvimento que poderão ser potenciadas no território;

-um terceiro cenário realista que serviu de base para uma proposta exploratória de estrutura urbana (ANDRADE, 2016:57);

O cenário tendencial surge através da análise das expectativas de crescimento urbano em consonância com a mais recente dinâmica de crescimento populacional do Mindelo, constituindo o cenário que dá continuidade à dinâmica de crescimento atual seguindo os principais eixos de expansão e ocupando as principais encostas que envolvem a cidade . É 
um cenário de continuidade do modelo de crescimento em mancha de óleo pressupondo também uma certa evolução na continuidade das práticas de gestão urbanística, de fraco controlo do licenciamento urbanístico e de planeamento passivo.

O cenário voluntarista, é o mais interventivo, e pressupõe maior proatividade da administração para potenciar os principais valores e vantagens comparativas da ilha no sentido de um desenvolvimento mais sustentável a par da vontade em empreender as correções indispensáveis, particularmente no que respeita ao maior controlo da ocupação.

Por fim, um cenário mais realista que visa integrar a capacidade de gestão e de planeamento com os recursos públicos disponíveis em face das potencialidades ambientais, socioculturais e territoriais. Procura-se conter, dentro do possível, a expansão da cidade em mancha de óleo, e satisfazer as reais necessidades habitacionais e de equipamentos da cidade, propondo áreas específicas para o desenvolvimento dessas dinâmicas, assim como áreas para o crescimento industrial e turístico, conforme as necessidades atuais e previstas.

\subsection{Elementos estruturantes}

Este exercício de cenarização foi depois conjugado com a identificação dos seguintes espaços:

10 Espaços Invariantes, de natureza biofísica (invariantes biofísicos), socioeconómica ou infraestrutural, que não são suscetíveis de mudar no médio-longo prazo, nomeadamente as linhas de água, os acidentes orográficos mais importantes que não se alterarão, devendo por isso ser tidos em consideração. Dada a situação orográfica e climática da ilha de $\mathrm{S}$. Vicente foram identificadas as linhas de águas principais de carater não permanente e os acidentes orográficos localizados acima da cota dos 100 metros de altitude (Fig.5).

20 Os espaços estruturantes resultantes da atividade humana organizam espacialmente uma cidade. São "pilares" determinantes na sua vitalidade, definindo uma forma própria de funcionamento em face das interdependências que criam (por exemplo uma fábrica, uma centralidade). Podem ser agrupados em 4 ou 5 categorias conforme as necessidades, a saber: as infraestruturas viárias e de transporte, onde foram identificadas as estradas de nível 1 e 2 e as vias de carater urbano, para além das infra-estruturas portuária, aeroportuária e militares; as grandes áreas de atividades económicas, nomeadamente as áreas industriais, de serviços; as centralidades e o Núcleo Histórico, para além dos grandes equipamentos e dos espaços públicos mais importantes e as áreas verdes. 
3을 Espaços indefinidos que podem ser áreas não ocupadas com construção urbana e sem utilização evidente, ou zonas sem uso definido (ANDRADE,2016:47). Os mais evidentes foram as zonas altas dos cumes das colinas da cidade do Mindelo, para além de algumas zonas baixas em leitos de cheia.

4을 Espaços Problemáticos são áreas já ocupadas mas que apresentam problemas de diferentes tipos, nomeadamente conflitos de utilização que devem ser resolvidos. Por exemplo foram identificadas como áreas-problema as zonas dos leitos de cheias das principais linhas de água atualmente impermeabilizadas que atravessam a cidade do Mindelo.

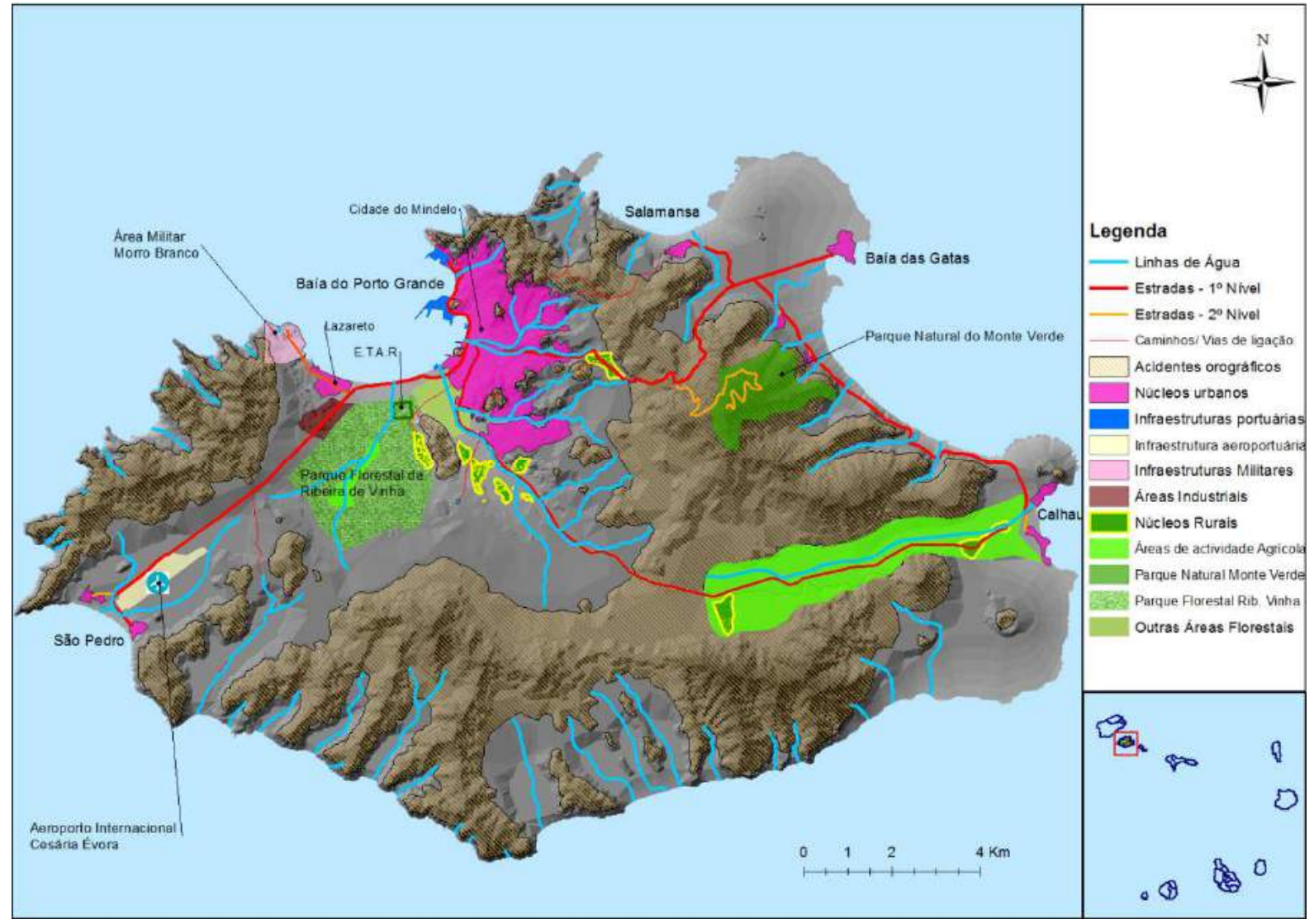

Fig. 10: Elementos estruturantes da llha de S. Vicente (ANDRADE,2016:50)

\subsection{Proposta de estrutura da Ilha de S. Vicente}

A identificação dos invariantes biofísicos, dos elementos estruturantes, indefinidos e os elementos problemáticos revelou-se útil porque facilita a elaboração de uma síntese de diagnóstico da situação da cidade do Mindelo e da ilha de S. Vicente. Tendo em vista uma melhor orientação da sua futura expansão urbana, foi elaborada uma proposta de estrutura 
para a ilha de S. Vicente que procura integrar este diagnóstico e responder aos desafios que se colocam à ilha e à cidade.

A 1a valência da ilha é o seu caracter eminentemente urbano, com a principal aglomeração, a cidade do Mindelo, a merecer uma abordagem específica tendo em consideração as principais componentes do sistema urbano, nomeadamente a satisfação das necessidades habitacionais, a expansão do tecido industrial, os sistema de infraestruturas, e as atividades de terciário e turísticas.

A 2a valência considerada foi a componente ambiental. Para evitar a ocupação por atividades económicas, urbanas ou turísticas de áreas com risco ambiental associado e assim impedir o seu comprometimento ambiental, propõe-se a constituição de áreas de reserva paisagística (englobando os principais acidentes orográficos da ilha, assim como as áreas de risco vulcânico).

A 3a valência é a componente económica, tendo o turismo como motor do desenvolvimento futuro da ilha, mas salvaguardando as especificidades próprias da mesma. Por forma a desenvolver a economia da ilha, também se deve atender à sua capacidade portuária, sem entrar em choque com as outras opções estratégicas, como a revitalização urbana e o turismo.

A visão estratégica de desenvolvimento futuro tem como objetivo principal a garantia dum desenvolvimento urbano harmonioso através da valorização das valências ambientais. Depois do sistema urbano do Mindelo ter sido estudado através da caracterização dos seus elementos estruturantes, chegou-se à conclusão que a cidade deverá desenvolver-se em áreas que não põem em risco o sistema ambiental, evitando a ocupação das linhas de água e os mais expressivos acidentes orográficos, sendo vedada a expansão urbana a altitudes superiores aos 100 metros, servindo estas como áreas de reserva paisagística onde poderão ser criadas novas áreas protegidas. (Fig. 11).

Para suscitar a renovação urbana da cidade, as infraestruturas portuárias devolutas existentes junto ao litoral deverão ser reconvertidas, assim como as estruturas industriais existentes incompatíveis com o edificado, devendo ser relocalizadas no parque industrial do Lazareto. Na mesma ótica, a estrutura do Porto Grande deverá ser aproveitada para a transformação do mesmo em Porto de Cruzeiros por forma a valorizar o turismo de recreio na baía do Porto Grande. Para manter a viabilidade económica da ilha, parece justificar-se a construção dum novo porto comercial em outra localização, a Sul da Ilha, fora da baía do Porto Grande, que poderá abarcar a potencialidade de ser um porto de águas profundas aproveitando a proximidade do aeroporto numa lógica de complementaridade. 


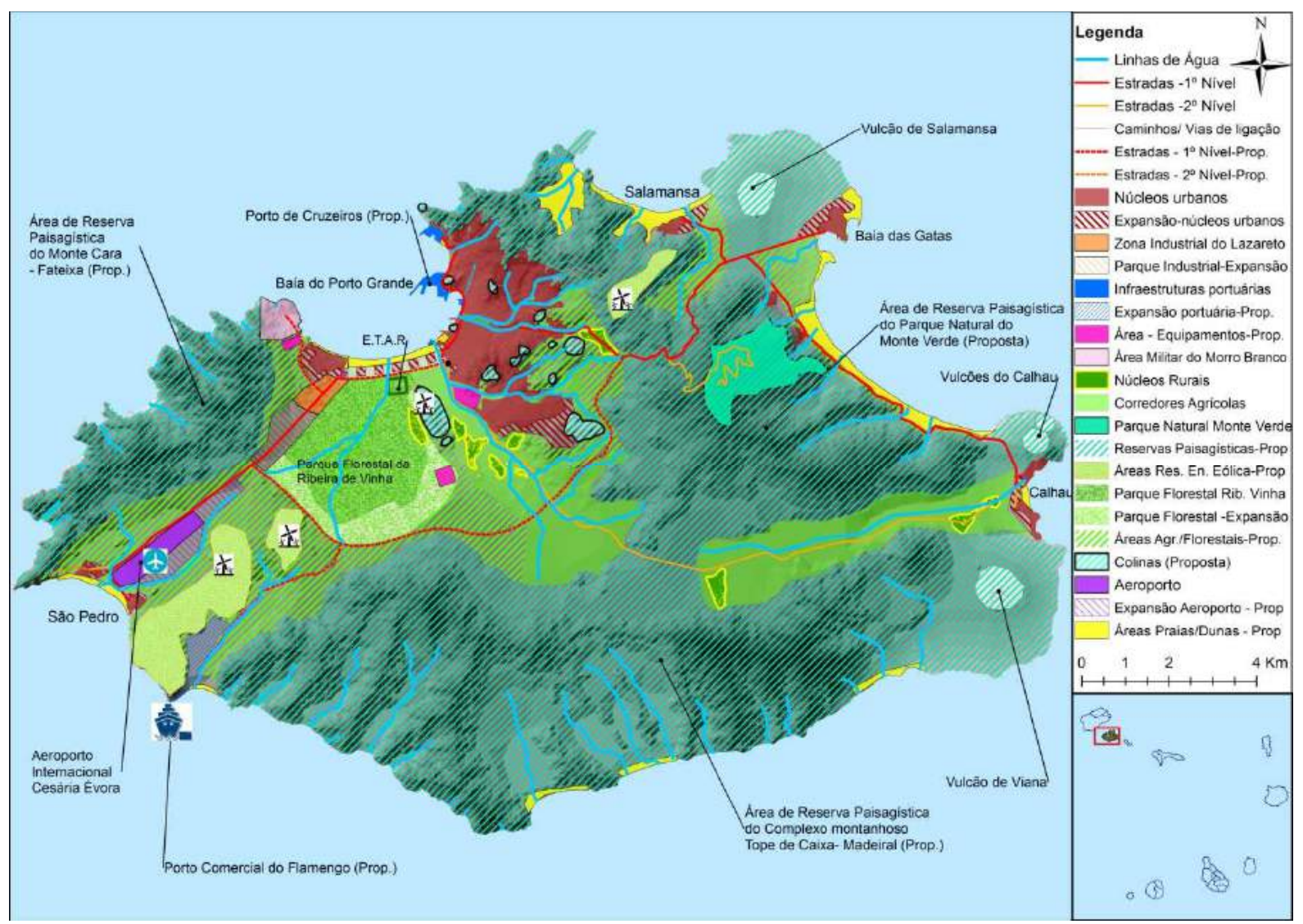

Fig. 11 - Proposta de estrutura para a cidade do Mindelo (ANDRADE,2016:74)

O desenvolvimento económico da ilha de S. Vicente deverá ser alavancado em alguns projetos nevrálgicos, não só o aproveitamento portuário duma ilha com tradição na área, assim como o aproveitamento das valências de desenvolvimento turístico da ilha. Contudo, esses projetos deverão realizar-se em articulação com a salvaguarda ambiental e urbanística.

Assim, o turismo não deverá continuar a ser visto na ótica das ZDTI (Zonas de Desenvolvimento Turístico Integrado $)^{3}$ pois não fornecem garantias dum desenvolvimento turístico integrado. A aceitação indiscriminada de resorts nas ilhas de Cabo Verde tem levado à descaraterização ambiental e obrigado as câmaras a promover a extensão da infraestrutura urbana fora das zonas de planeamento faseado com custos elevados. Além do mais, é uma política de desenvolvimento turístico que não promove o desenvolvimento

\footnotetext{
${ }^{3}$ ZDTI- Zonas de desenvolvimento turístico integrado- Áreas delimitadas pelo Governo de Cabo Verde em todas as ilhas de Cabo Verde, com vocação turística, destinadas a construção de grandes empreendimentos turísticos com vista a prática do turismo de sol, praia e mar. Em Cabo Verde existem 25 ZDTI, sendo 7 em S. Vicente, abrangendo estas cerca de $50 \mathrm{~km}^{2}$ da ilha de S. Vicente $\left(227 \mathrm{~km}^{2}\right)$. Em S. Vicente, a maior parte das ZDTI não se encontram ainda exploradas devido ao fraco investimento turístico gerado nos últimos anos
} 
cultural e social das populações nem garante uma melhor distribuição económica dos recursos pelas atividades da ilha. Tudo recomenda que a atividade turística não seja encapsulada em "resorts", mas passe a ser mais integrada com a vida social e cultural dos núcleos urbanos existentes promovendo o seu caracter genuíno e o seu desenvolvimento económico.

O modelo de desenvolvimento turístico adotado nas ilhas vizinhas das Canárias, já bastante reproduzido nas ilhas cabo-verdianas do Sal e da Boavista deve ser posto em causa, devido ao facto de constituir um modelo pouco inclusivo, na medida em que a construção de "resorts" em nada contribui para a participação do turista na cultura local. Os resultados, económicos para a região tendem a ser limitados, pois o turista tende a preferir o consumo nos "resorts", que na maioria pertencem a sucursais estrangeiras.

Parece também inevitável a necessidade de novas infraestruturas viárias que poderão ligar as principais infraestruturas da ilha (o porto e o aeroporto), com os principais núcleos urbanos da ilha, garantindo uma boa rede de acessos e algum descongestionamento da circulação na própria cidade do Mindelo. Também uma melhor ligação marítima da ilha de S. Vicente com a vizinha de Santo Antão, pode resultar em melhor complementaridade funcional devido ao elevado potencial agrícola e do turismo rural de Santo Antão. Historicamente esta ilha funciona como principal ponto de abastecimento diário dos produtos alimentares necessários à S. Vicente. Por outro lado, as boas capacidades de alojamento turístico da cidade do Mindelo complementam a atratividade turística de Santo Antão.

\section{Conclusão}

Neste artigo expõem-se essencialmente quatro componentes importantes para a elaboração de uma proposta de estrutura territorial: a análise da evolução histórica do Mindelo; a caracterização biofísica do território; o mapeamento da evolução urbanística; a identificação dos elementos estruturantes. 
Pode concluir-se sucintamente pela análise da evolução histórica que o desenvolvimento económico é determinante para o desenvolvimento social e urbanístico desta cidade-ilha. Sem recursos biofísicos e geológicos importantes nem especificidades próprias ou qualidades significativas relativamente a outros lugares, São Vicente-Mindelo terá de afirmar a sua riqueza cultural e os valores ecológicos-ambientais únicos em complementaridade com Sto. Antão para potenciar a sua atratividade turística. A análise dos instrumentos urbanísticos e da evolução da mancha urbana parecem indicar a necessidade de resolver problemas críticos de infraestruturação, de ocupação de leitos de cheia e a necessidade de superar enormes fragilidades a nível do controlo da ocupação/ edificação. A defesa de uma estrutura base para o desenvolvimento deste território pode assentar em três eixos estratégicos principais: o crescimento urbano da cidade do Mindelo estruturado em torno de um modelo de desenvolvimento económico da ilha de S. Vicente alavancado no turismo, no desenvolvimento portuário e na valorização ambiental para um horizonte de 20 a 30 anos.

Tratando-se de uma cidade-ilha é essencial atender ao cálculo dos limiares de capacidade, como por exemplo a capacidade da ETAR, do Aterro Sanitário, da Estação de Dessalinização, a programação dos equipamentos, que neste artigo não são apresentados.

A elaboração de uma proposta de estrutura territorial (diferente de uma proposta de zonamento do uso do solo) apresenta vantagens relacionadas com a integração expedita de estratégias de desenvolvimento e de modelos territoriais de ocupação sem ser necessário detalhar o desenho e localização rigorosa de usos e atividades. Isto não significa que possa dispensar-se a elaboração de um subsequente Plano para a llha ou para a cidade. Significa apenas que podemos fazê-lo em focagens progressivas, começando desejavelmente por uma proposta de estrutura como aqui pretendemos exemplificar.

\section{Referências Bibliográficas}

AGUIAR, João (1959). Urbanização do Mindelo. Esboceto. Depositado no Arquivo Histórico Ultramarino (IPAD8058), Lisboa

AMORIM, José Luís (1960). Plano Diretor-Base do Mindelo. Zonamento. Urbanização do Mindelo, Plano Diretor-Base, 1960, vol. I. Depositado no Arquivo Histórico Ultramarino (IPAD 1149), Lisboa 
ANDRADE, Dénis da Graça (2016). Evolução da Estrutura Urbana da Cidade do Mindelo. Contributos para um plano de Estrutura. Lisboa: Instituto Superior Técnico, Universidade de Lisboa - Tese de mestrado em Urbanismo e Ordenamento do Território. Discussão Pública a 23/11/2016

CMSV - CÂMARA MUNICIPAL DE S. VICENTE (2011). Relatório do Plano Diretor Municipal de S. Vicente. Mindelo. S. Vicente.

CÁRIA, Maria Emília (1969). Urbanização do Mindelo. Plano Diretor. Urbanização da Cidade do Mindelo- Plano Diretor, 1969. Depositado no Arquivo Histórico Ultramarino (IPAD 1222), Lisboa.

DGOTDU - DIRECÇÃO GERAL DE ORDENAMENTO DO TERRIÓRIO E DO DESENVOLVIMENTO URBANO (2012). Esquema Regional de Ordenamento do Território da Ilha de S. Vicente (EROT-SV). Disponível a 27/04/2017 em: http://www.sia.cv/index.php/documentacao-mainmenu/category/6-erot-sao-vicente

DGOT - DIRECÇÃO GERAL DO ORDENAMENTO DO TERRITÓRIO (1995). PDM da Ilha de S. Vicente- PDU da Cidade do Mindelo. Consórsio AIP/Tectoplaca. S. Vicente/Goteborg.

FERNANDES, Sérgio Padrão (2016). Cidades imaginadas nos planos de urbanização de Cabo Verde, 1934-1974. Lisboa: Editora Argumentum.

INCV - IMPRENSA NACIONAL DE CABO VERDE (2006). Lei de Bases do Ordenamento e Planeamento Urbanístico. Decreto-Legislativo no1/2006 de 13 de Fevereiro. I Série- no 7 do “B.O." da República de Cabo Verde. Disponível em: http://www.sdtibm.cv/documentos/BO/bo I 13-02-2006 7.pdf

INCV - IMPRENSA NACIONAL DE CABO VERDE (2014). Esquema Regional de Ordenamento do Território de S. Vicente. Resolução no resolução n.o 4/2014 de 8 de Janeiro- I Série. № 2 do “B. O.” da República de Cabo Verde. Disponível a 31/10/2016 em: http://faolex.fao.org/docs/pdf/cvi130663.pdf

INECV - INSTITUTO NACIONAL DE ESTATÍSTICA DE CABO VERDE (2010). Relatório de apresentação dos dados preliminares do IV Recenseamento Geral da População e Habitação de Cabo Verde de 2010. Disponível em: http://www.portaldoconhecimento.gov.cv/bitstream/10961/170/1/Setembro,\%202010\%20RELATORIO\%20RE SULTADOS\%20PRELIMINARESR\%20RGPH\%202010\%20final.pdf

INECV - INSTITUTO NACIONAL DE ESTATÍSTICADE CABO VERDE (2015a). Anuário Estatístico de Cabo Verde do ano 2015. Praia. Cabo Verde. Disponível em: http://ine.cv/wp-content/uploads/2017/02/anuarioestatistico cv-2015.pdf

INECV - INSTITUTO NACIONAL DE ESTATÍSTICA DE CABO VERDE (2015b). Produto Interno Bruto (PIB) por ilhas (Série 2007-2012). Praia. Cabo Verde.

INECV - INSTITUTO NACIONAL DE ESTATÍSTICA DE CABO VERDE (2016). Evolução da população residente em Cabo Verde, 1900-2010. Disponível em: http://ine.cv/quadros/evolucao-da-populacao-residente-em-caboverde-1900-2010/

PAPINI, Brita, coord. (1984). Linhas gerais da história do desenvolvimento urbano da cidade de Mindelo. Ministério da Habitação e Obras Públicas de Cabo Verde. Edição do Fundo de Desenvolvimento Nacional, Ministério da Economia e Finanças. Praia.

PFEIFFER, Peter et al. (1979). Plano Diretor de Mindelo. Cooperação técnica Cabo Verde FU/HdK/TU. Berlin. SILVA, A. E. (1995). O litígio entre Portugal e a ONU (1960-1974). In Análise Social, vol. XXX(130)-1, pp5-50. 